\title{
Conversation Stations and Basic Mental Entities as Linguistic Phenomena in Children Language Development
}

\author{
Mohammad Halili ${ }^{1}$, Darul Hikmah ${ }^{2}$ \\ \{mohammad.halili@trunojoyo.ac.id ${ }^{1}$,darul.hikmah@trunojoyo.ac.id²\} \\ 1,2Universitas Trunojoyo Madura, Bangkalan, Indonesia
}

\begin{abstract}
Infants experiencing difficulties in expressing an object or describing events in time do not necessarily mean that their mind stops processing the language. We, however, should persistently provide enough room to them for talk that is beneficial for their later development. Unluckily, children, to some extend, lack of opportunities to have meaningful conversations, rich vocabularies, and complex sentences modelled by their parents or caregivers. The current research, thus, aims to investigate how the implementation of conversation stations relates to children language development. This employs the qualitative research design, involving 4 children aged 4 . To identify the linguistic features that the participants presumably show, basic mental entities column were also made as data collection guidance. Through the exchanges, children can describe events and situations, attributes, modifiers, and evaluation of events and situations, research shows. Conversation stations help children to develop linguistically.
\end{abstract}

Keywords: Conversation stations, exchanges, evaluation, language development

\section{Introduction}

Language development for children is an achievement. However, not all can achieve in a similar level due to the poor opportunities they might have to improve. This can be a number of reason that underlies those experiences. The small room that the children might have in expressing themselves due to verbal crimes for instance can lead to linguistic problems. It can be exemplified by the facts that they suffer from selective mutism and language delay. Taking this as a serious problem can be considered to be fundamental foundation to build an individual awareness to see the importance of having more talk time with children while they are in development period in particular. This research is, thus, mainly concerned about what the linkage of the implementation of conversation stations to children language development is.

The conversation stations is a classroom setting designed to invite the child to engage in a more talk session. It aims to promote various vocabularies, to model rich language reflected by the use of more complex sentences, and to provide feedback on child performance. According to Bond and Wasik (2009), the conversation stations have two important roles: thoughtful listening and the art of conversation. The first notion refers to the situations in which the competent speaker and child engaged in a conversation considerately. When teacher talks, it is expected that the child can listen to what he/she said attentively so that they can provide an appropriate response. On the other hand, the conversation stations allow us, 
teaching staff and children, to practice the art of conversation. Face-to-face exchange can set a setting to introduce and extend theme concept, use new words, and more importantly, let us to learn the children's interest and learning.

In the conversation stations, we purposefully designed the topic that are neither complex, hindering children to engage in the meaningful conversation, nor too simple, making them bored to participate in the exchange. In the current context, the topics are related to transportation, animals, but not limited to. In other words, we brought the topics in it that may attract their attention. However, if it does not work such as the child does not show any interest in or simply keeps silent, tentative topics could be optional. We can randomly take an object of event around them to discuss. When they proposed new idea such as telling his/her personal experiences while going to zoo for instance, it must be a tremendous chance to us to be his/her 'friend'. Therefore, listening attentively to what they said is worthy of notice. In this occasion, we do not stop them to share his own topic with. This is to avoid such assumption that their topic is not or less important, encumbering them to demonstrate themselves. It can be perceived that there is a need to follow the stream and we engage in the conversation in which the topic was introduced and was initiated by the children. This is to trigger them to extend and expand their stories. Indeed, it is useful for children to speak their mind.

In this context, we have a colorful book consisting of valuable information relating to vehicles and animals. In practical terms, we open and show the book to them. When we point one object of pictures for instance, we ask the child "ini gambar apa?" (what is it?"). The question is meant to discover whether the child (does not) knows the object and express it verbally. If he/she has no ideas about, indicated by silence for instance, we help him/her to say the word. Furthermore, we ask an open-ended question to further self expression. It can be exemplified by "Ade suka mobil ini. Kenapa?" (You like this car. Why?). This question is handy enough to stimulate children to use richer vocabularies such as attribute and modifier in their response. In addition, having more open-ended questions can give children to any wider possibilities to describe the event and provide evaluation to the event.

In respect to the intervention given, it is also important to note that language development for children is personal, meaning that every single child can show distinctive modes of language performance even though they are in the same level of ages. It can be due to a number of factors either nature or nurture. This could be an argument why children in the same age or around could achieve the language performance in different level. For intance, it is strongly argued that children age 2 to 3 can increase many words to count and are able to combine two or three words into a meaningful sentence. However, a number of children can have a different language development experience.

We might have a question in our mind why assisting children language development is important. It has nothing to do with unless for conversational purposes either in family, school, or society in a wider scale. If it does not occur, the problems presumably arise. For instance, the children suffer from the speech delay and selective mutism. The children can be said to experience speech delay when they are unable to comprehend and produce the language in the given ages. Aged 18-24 months, normally children can produce holophrastic speech, one word to describe many things. For example, a young child may point a pair of shoes by saying 'mama' which means 'The shoe belongs to mama' (Steinberg, Nagata, \& Aline, 2001). Other can refer to the situation in which he/she wishes to have some drink or food. Semantically, the word 'mama' has no denotative meaning (a woman delivering a baby or informal expression for mother). According to Groß, Linde, and Ostermann (2010), children who delayed their language performance are more at risk of their cognitive 
development, social-emotional, and school-related problems. Therefore, it is crucial to know and to assist the development of children's language performance.

The other problem is that they can suffer from Selective Mutism (SM). It means that the children fail to speak up while they are not mute. SM is characterized by an absence of speech in specific public situations in which the child is expected to speak, in school for instance, but it is normal when he or she is at home (Muris, Hendriks, \& Bot, 2016, Oerbeck, Stein, Pripp, \& Kristensen, 2015). For instance, the question to "apa kabar?" (How are you?) has no response. It may occur again when the extended questions given. So, the children just keep silent while others are trying to communicate messages.

Research relating to children language development is numerous. According to Bates, Thal, Whitesell, Fenson, and Oakes (1989), and Halili (2017), gesture and the development of children language are integral. Ruangdaraganon, Chuthapisith, Mo-Suwan, Kriweradechaichai, Udomsubpayakul, and Choprapawon (2009) also believe that watching television longer than 2 hours per day did not associate with delayed language development. Chandrasekar (2008) also addressed the issue how children learn to communicate, describe, manipulate, and explore the world around them. However, discussing the conversation stations as a major concern on the analysis can be said rare. One of the related work can be credited to Bond and Wasik (2009). They put emphasis on technical matters instead of demonstrating the findings of the research. They provide more room to talk the role of conversation stations, how to create conversation stations and its guidelines, the roles of the teacher, child-initiated conversations, and teacher-initiated conversations. Only small room available to show the evidence of the conversation stations based on the research basis.

What makes the current research differs significantly from the previous ones is that the design of basic mental entities as the linguistic indicators presents. The design was unavailable in each cited references. The column has never been available on the same or similar field of research previously. Indeed, this indicator facilitates us to acquire the measurable components of the linguistic research evidence easily so that the important information pertaining to linguistic aspects of the children language development is well presented. For that reason, this research has strategic position to be investigated.

\section{Method}

This employs a qualitative research design. According to Aspers and Corte (2019), qualitative reserach is defined as an interactive process in which improved understanding to the scientific community is achieved by making new significant distinctions resulting from getting closer to the phenomenenon studied. The approach is relevant because the current investigation aims to see the interwoven between the implementation of conversation stations and the children language development. There were five (4) children aged 4 participating in this important chance. They are all students at TSA (Taman Sosialisasi Anak), located at Universitas Trunojoyo Madura. 27 children officially registered here. The participants' selection is based on the fact that most of TSA students are under two years old that may have lack of experiences to engage in a particular topic in a longer and well developed exchange. Therefore, they are not chosen. The selected participants are subsequently set in conditions to have a meaningful conversation, rich vocabularies, and more room available to express themselves. The talk was recorded to obtain authentic data and guard them from lost. The experiment run for four days during the working hours applied to the same participants. 
During the process of data collection, the table of the basic mental entities made to assist and verify the linguistic features that they performed. The expressions filled in the table are the chosen data to be scrutinized how the implementation of conversation stations is asssociated with the children development linguistically.

Since the linguistic aspects of the children examined, the language parameters established to assess in what ways children develop linguistically. The column of the basic mental entities is specifically designed to help us easily identify, recognize, and state to what extend the application of the conversation stations carries impact on the children verbally. One table is applied to one child so that each denotes participant's information of his/her linguistic performance. The basic mental entities is best described below:

Table 1. The Column of the Basic Mental Entities

\begin{tabular}{|c|c|c|c|c|}
\hline No & Objects & $\begin{array}{l}\text { Attributes \& } \\
\text { modifier }\end{array}$ & Events & $\begin{array}{l}\text { Attributes, modifiers, and evaluation of the } \\
\text { events and situations }\end{array}$ \\
\hline
\end{tabular}

The basic mental entities have five columns. Each colomn indicates the linguistic aspect that the children show. Object refers to a specific noun they name. Attributes and modifier are used to describe the given object such as the use of adjectives. Event means that the object involves in an activity. Meanwhile, the last column explains how the basic proposition is modified by other predicates so that it has more complex proposition such as the use of complex sentences, compound sentences, and adjective clauses. The language of the data is Bahasa Indonesia which is translated into English (in the same column) to assist the potential readers from different language background or unfamiliar with.

The chosen data, based on the above column, subsequently analyzed to see the interwoven between the application of conversation stations and children language development. In the analysis, we explain each child's language performance based on the achievement stated in the given column. In other words, detail description of each participant's language competence is illustrated.

\section{Results and Discussion}

This section presents the findings of the study of the implementation of conversation stations in relations to children language development. The basic mental entities as a child language indicator and their explanation in the given conversation stations follow. The following table depicts basic mental entities successfully appeared during the conversation with the first child:

Table 2. Basic Mental Entities of the First

\begin{tabular}{lllll}
\hline No & Objects & Attributes \& Modifiers & Events & $\begin{array}{c}\text { Attributes, modifier, and evaluation } \\
\text { of the event and situation }\end{array}$ \\
\hline 1 & Gajah & Gajah besar. & (The & $\begin{array}{l}\text { (gajahnya) } \\
\text { makan. } \\
\text { (Elephant) } \\
\text { elephant } \\
\text { eating) }\end{array}$ \\
\hline
\end{tabular}




\begin{tabular}{|c|c|c|c|c|}
\hline No & Objects & Attributes \& Modifiers & Events & $\begin{array}{c}\text { Attributes, modifier, and evaluation } \\
\text { of the event and situation }\end{array}$ \\
\hline 2 & Pohon (Tree) & - & $\begin{array}{lr}\text {-Aku } & \text { naik } \\
\text { pohon. } & \text { (I } \\
\text { climbed a tree). }\end{array}$ & $\begin{array}{l}\text {-Aku punya pohon dan pohonnya } \\
\text { sampek kena hujan. (I have a tree and it } \\
\text { is poured by the rain.) } \\
\text { Tapi aku gak bisa naiknya.karena nanti } \\
\text { aku jatuh. (I cannot climb the tree } \\
\text { because I fall down). }\end{array}$ \\
\hline 3 & $\begin{array}{l}\text { Ikan hiu } \\
\text { (Shark) }\end{array}$ & $\begin{array}{l}\text { Ikan hiu itu jahat (The } \\
\text { shark is wicked.) }\end{array}$ & $\begin{array}{l}\text { (di lautan) ada } \\
\text { ikan hiu. (there } \\
\text { is a shark in the } \\
\text { ocean.) }\end{array}$ & $\begin{array}{l}\text { Ikan hiu itu jahat soalnya itu hewan } \\
\text { kataku. (The shark is wicked because it } \\
\text { is an animal i said). }\end{array}$ \\
\hline 4 & Ular (Snake) & $\begin{array}{l}\text {-Ular warnanya hijau. } \\
\text { (The snake is green.) } \\
\text {-(ularnya) ada } \boldsymbol{d u a}\end{array}$ & $\begin{array}{l}\text { Aku pernah } \\
\text { lihat ular di } \\
\text { rumah. (I ever } \\
\text { saw the snake } \\
\text { at home). } \\
\text { Kalo (ular) } \\
\text { yang besar itu } \\
\text { sudah mati. } \\
\text { The big snake } \\
\text { is died.) }\end{array}$ & $\begin{array}{l}\text { Aku berani (sama ular) soalnya kakakku } \\
\text { diusir. (I have no problem with the } \\
\text { snake because my old brother expelled } \\
\text { it.) }\end{array}$ \\
\hline
\end{tabular}

In this context, the child prefers to talking about something she has experienced and known rather than to talk about something she does not know. When the column is blank, it indicates that the child did say anything about the object such as to modify or shift to the other topic. For example, she likes to talk about elephant, ship, fish, tree, all of which she has been familiar with. In the column, we can find a number of objects named by the participant. Focusing on the object number 2 (pohon / tree), the attribute and modifier are absent. It means the child did not modify the noun by using adjective for instance. However, looking at the column "event", the child can describe the event about the tree, how the object involves in an activity (aku naik pohon). It is clear that the child used a simple structure of the sentence. In contrast, the column of evaluation indicates to which the child uses the compound sentence (Aku punya pohon dan pohonnya sampek kena hujan / I have a tree and it is poured by the rain.). The use of word 'dan' (and) indicates that the child is able to connect and idea to the next. The child's linguistic performance shows how the participant can demonstrate further explanation about the issue at hand.

She also likes to tell us what she feels and what she likes about the objects being discussed during the conversation in the conversation station. She is happier to choose the topic of conversation herself rather than the topic provided by the teacher. For example, the data No. 3 describes the object (ikan hiu / shark) and the child is also able to modify the object by the use of adjective (jahat/wicked). Interestingly, we can find a more complex sentence in the given column (Ikan hiu itu jahat soalnya itu hewan kataku / the shark is wicked because it is an animal). Regardless the syntaxtical and semantic aspects of the sentence (the sentence does not make sense semanttically due to the additional kataku without pause (no comma) so that the meaning conveyed seems bias), it is a complex one because the sentences consist of cause and effect.

Data 4 (Aku berani (sama ular) soalnya kakakku diusir.) also show a complex sentence. The presence of the reasoning expression (soalnya / because) makes the simple proposition (Ikan hiu itu jahat.) becomes more complex (... soalnya itu hewan kataku). The major issue is also applicable to data 4 in which the simple proposition (Aku berani (sama ular)) turns into a more compex sentence. They highlight that when we can give more room to children to 
express themselves and simultaneously we are good listeners to them, a meaningful conversation can take place.

It is also worthy of notice that this child regularly can develop and elaborate her personal experience and imagination about the object being discussed. She is able to elaborate an object by mentioning the attributes. Often, she is able to involve the object in an event of her sentence, without any stimulus (e.g. question, feedback, and its kind) from the teacher. In terms of giving evaluation, however, she often needs such stimulus first from the teacher. The child is often stuck to give an evaluation of the object. It seems that she frequently requires such stimulus from the teacher indicated by a long lull after describing the event. To discover such situation, the teacher often uses question "why" to stimulate the child to give evaluation of the object. For instance, the teacher questions the child "kenapa kok gak bisa naiknya?" when the child tells that she cannot climb a tree. After listening to the question (i.e stimulus), the child responsively answers "karena nanti aku jatuh". This shows that conversation station where various strategies can be applied is an effective medium for children language development. The following table also depicts some mental entities successfully appeared during conversation with the second participant:

Table 3. Basic Mental Entities of the Second Participant

\begin{tabular}{|c|c|c|c|c|}
\hline No & Objects & Attributes \& Modifiers & Events & $\begin{array}{c}\text { Attributes, modifier, and evaluation } \\
\text { of the event and situation }\end{array}$ \\
\hline 1 & TV & $\begin{array}{l}\text { TVnya warna hitam, } \\
\text { red. (The TV is black, } \\
\text { red.) }\end{array}$ & $\begin{array}{l}\text { TVnya ada satu. } \\
\text { (There is one } \\
\text { TV.) }\end{array}$ & - \\
\hline 2 & $\begin{array}{l}\text { Gajah } \\
\text { (Elephant) }\end{array}$ & (gajah) besar & $\begin{array}{l}\text { gajahnya maem. } \\
\text { (The Elephant is } \\
\text { eating). }\end{array}$ & - \\
\hline 3 & $\begin{array}{l}\text { Rumput } \\
\text { (Grass) }\end{array}$ & (rumput) bagus & - & - \\
\hline 4 & $\begin{array}{l}\text { Capung } \\
\text { (Dragonfly) }\end{array}$ & - & $\begin{array}{l}\text { Capung terbang. } \\
\text { (The dragonfly } \\
\text { flies.) }\end{array}$ & $\begin{array}{l}\text { Capung terbang untuk cari makanan } \\
\text { karena lapar. (The dragonfly flies to } \\
\text { find food because it is getting hungry.) }\end{array}$ \\
\hline
\end{tabular}

In terms of interest, the second child is similar to the first child. She is happier to talk about something she has known rather than something she does not know. She also prefers to choosing the topic of herself rather than the topic provided by the teacher. However, even though in the same range of age, this child linguistically develop slower than the first one. She is mostly able to mention the object, but not able to mention directly the attribute of the object. She is often stuck to elaborate the object. She often needs stimulus from the teacher first in order to be able to express the attribute. She is also hardly constructs longer sentence. She is often hard to involve objects in an event or situation. Since the observation in the conversation station, this child cannot elaborate, at all, the object further.

Furthermore, she is also very hard to give evaluation. In this case, the teacher tried to discover the problem by guiding the child with some questions and starting point. For example, after the child mentions objects, such as ' $T V$ ', 'gajah', 'rumput', and 'capung', and she is stuck to elaborate more about the objects, the teacher stimulates the child with question "Di rumah adek punya TV?", "Punya berapa?", "Warnanya apa?", "Rumputnya berwarna ...", "capung itu terbang atau jalan?", "kenapa ya capung kok terbang? And Mau ngapain?". As a result, the stimulus given by the teacher works as expected. The data 4 for instance, in the column evaluation, the child can make a simple proposition even complex by using the reasoning expression 'karena / because' in the sentence. The child is able to mention some 
attributes (Data 1, 2, and 3), event (in very short phrase), and sometime is hardly able to give evaluation.

The following table is provided to show some mental entities gained in the conversation stations with the third child:

Table 4. Basic Mental Entities of the Third Participant

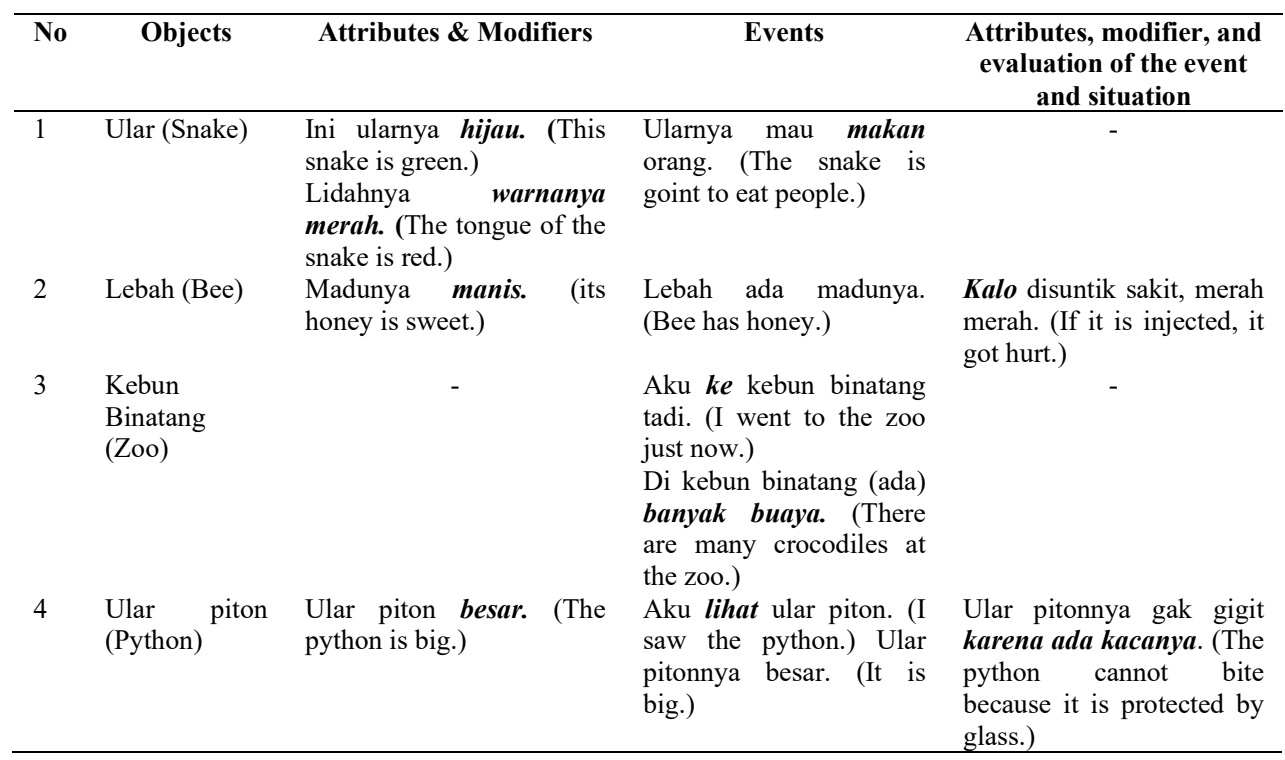

In terms of language expression, this child is higher than the second child. He is in the same range of age with the two children mentioned previously. His language development is in the level of the first child. He can easily mention the objects shown to him and give attributes to the objects. Besides, he is also able to involve the object in events or situations. The only thing that he cannot elaborate very well is the evaluation. He cannot, all the time, directly give evaluation about the event or situation involving the objects. Sometimes, he needs guidance or stimulus first from the teacher to be able to give evaluations. For this, the teacher stimulates the child with open-ended question 'why', such as "kenapa ya kudanya kok makan rumput?", when the child is hardly think what to say next after mentioning an event that a horse eats grass. Such question works. He, then, can tell the teacher why it is so.

In addition, similar to the two other children previously mentioned, he is happier to choose the topic himself, because he likes to talk about what he has experienced with the objects in the topic. He is very excited to tell the teacher about his own experiences during the conversation in the conversation stations, using longer sentences. For example, the child is really excited to tell the teacher his experiences when he went to zoo with his parents. He is excitedly mentions the various animals in the zoo, tells what they did and what he did with them. Indeed, the teacher sometimes still needs to respond to his story to show him that the teacher is still with him. The teacher responds by saying "terus terus...", "ada apa lagi di sana?", "mmm ... setelah itu...". Such action is very effective to help the child to develop his linguistic capacity.

The following table depicts some mental entities gained in the conversation with the forth child: 
Table 5. Basic Mental Entities of the Fourth Participant

\begin{tabular}{|c|c|c|c|c|}
\hline No & Objects & $\begin{array}{l}\text { Attributes \& } \\
\text { Modifiers }\end{array}$ & Events & $\begin{array}{l}\text { Attributes, modifier, and evaluation of the } \\
\text { event and situation }\end{array}$ \\
\hline 1 & $\begin{array}{l}\text { Sepeda } \\
\text { (Bicycle) }\end{array}$ & $\begin{array}{l}\text { Sepedaku } \\
\text { warnanya } \\
\text { merah. (My } \\
\text { bicycle is red.) }\end{array}$ & $\begin{array}{l}\text { Sepedaku dibeliin } \\
\text { mama sama ayah. } \\
\text { (My mom and my } \\
\text { daddy bought my } \\
\text { bicycle.) }\end{array}$ & $\begin{array}{l}\text { Aku dulu pakai roda empat sekarang roda dua. } \\
\text { ( I had a car (but) now I had motorcycle.) }\end{array}$ \\
\hline 2 & $\begin{array}{l}\text { Kebun } \\
\text { binatang } \\
(\text { Zoo })\end{array}$ & - & - & $\begin{array}{l}\text { Besok aku ke kebun binatang lagi tapi bukan } \\
\text { naik mobil, naik sepeda motor. Sama mamaku } \\
\text { sama ayahku. (I am going to go zoo again } \\
\text { tomorrow but not driving a car, motorcycle } \\
\text { instead. My mom and dad come along with } \\
\text { me.) }\end{array}$ \\
\hline
\end{tabular}

This last child is quite different from others. He is a bit moody. He needs an extra care and more attention from the teacher in order that he can be in a good mood to participate in the conversation. Sometimes he is not confident enough to tell something about an object and choose to be silent. To discover such situation, the teacher needs to try hard to attract him to speak. The teacher needs to stimulate him with something (or object) he loves, such as bicycle that he owns in his house. The teacher offers open-ended questions, such as "kakak Baghir katanya punya sepeda, adek Zafran punya sepeda juga?", "warnanya apa?", "dibelikan siapa?". Such strategy works as expected. He, then, responds to the question and starts to speak up and elaborates his bicycle, mentions some attributes related to the bicycle, tells the teacher how he rides it. The last column for second data is worthy of note. The child can utter long sentence.

We intentionally compare the current finding with Bond and Wasik (2009). The fundamental reason why their work is essential to this comparison is that their work seems original and appears to be inspired. More importantly, the research on this specific topic found to be rare or uncommon. Therefore, we see the importance of having the notion scientifically developed.

Their work focuses on how children develop linguistically due to the conversation stations. What we can highlight from the paper, however, is that they are mainly concerned about the issue from theoritical underpinning instead of supporting the ideas from occuring linguistic data. From page $469-472$ for instance, what make the paper interesting is that they provide useful insights to the ways how conversation stations can be applied, what their roles are, the guidelines of their application. Indeed, they appear to be more theoritical than practical. Furthemore, the helpful guidance on what ways the children acquire the language is absent. It has no a specific linguistic indicator to measure or to assess the effecs of conversation stations could bring.

The current research, on the one hand, is distinctive in a number of ways. The data of this paper is based on the occuring linguistic data, not theoritical framework instead. In other words, this paper is a research-basis. In addition, this research also provides a table of basic mental entities. It comprises the information of objects, attributes and modifier, events, and evaluation to the events. From that table, then we know the impact of the implementation of conversation stations for children langauge acquisition possibly carried.

The evidence above remarkably demonstrate how conversation stations can work effectively to stimulate children to express themselves. The wider room we provide to them 
can be handy to describe objects along with their attributes and modifiers. We also noted that the children can provide an evaluation to the object due the open-ended questions we proposed. It indicates that tremendous opportunities that we give to children can create not only a meaningful conversation between the teacher and the children, but also allow them to express themselves in more complex senteces. The basic mental entities are thus useful to easily identify in what ways children develop linguistically.

\section{Conclusions}

Conversation stations can bring positive impacts on children in a number of ways: 1) it gives more chances to children to give more detail description, 2) the researchers can introduce new words for what they have no idea about a special object to use, 3) it allows them to have longer talks, 4) it creats more meaningful conversation. From the basic mental entities eventually we are delighted in what ways linguistic features the children perform. They can describe the object, use attributes and modifier, illustrate the event, and display attributes, modifiers, and evaluation of the events and situations.

Due to the short periode of data collection, the findings cannot be significantly or strongly justified that implementation of the conversation stations is directly associated with children language development. We might need more data to support the stance, especially because the period of data collection is relatively short. Maintaining the focus of the children can be challenging too. Not only that, future research is important to study either feeling uncomfortable talking to 'strangers' could be a contributing factor to why children may hinder to speak a lot as expected compared to the interlocutor they speak to.

\section{Acknowledgments}

Our special thanks go to LPPM (Lembaga Penelitian dan Pengabdian Masyarakat), Universitas Trunojoyo Madura for this research grant. This sheds light on the understanding that working with children especially assisting their language development is worthy. LPPM can be reached at 0313011146,0313012391, or 1ppm@trunojoyo.ac.id.

\section{References}

[1] Aspera, P., \& Corte, U. (2019). What is Qualitative in Qualitative Research. Qualitative Sociology. 42:139-160.

[2] Bates, E., Thal, D., Whitesell, K., Fenson, L., \& Oakes, L. (1989). Integrating Language and Gesture in Infancy. Developmental Psychology. 25(6): 1004-1019.

[3] Bond, M., A., \& Wasik, B., A. (2009). Conversation Stations: Promoting Language Development in Young Children. Early Childhood Education Journal. 36:467-473 DOI: 10.1007/s10643-009-0310-7.

[4] Chandrasekar, R. (2008). How Chilren Learn to Use Language: An Overview of R Narasimhan's Ideas on Child Language Acquisition. Retrieved at 7 September 2019 from https://link.springer.com/content/pdf/10.1007\%2Fs12045-008-0050-9.pdf. 
[5] Groß, W., Linde, U., \& Ostermann, T. (2010). Effects of Music Therapy in the Treatment of Children with Delayed Speech Development - Results of a Pilot Study. BMC Complementary \& Alternative Medicine, 10:39.2-10.

[6] Halili, M. (2017). Gestures sebagai Concrete Paving dalam Pemerolehan Bahasa Anak. Pamator, 10(2):78-83. Retrieved from http://journal.trunojoyo.ac.id/pamator/article/view/4078.

[7] Muris, P., Hendriks, E., \& Bot, S. (2016). Children of Few Words: Relations among Selective Mutism, Behavioral Inhibition, and (Social) Anxiety Symptons in 3- to 6-Year-Olds. Child Psychiatry Hum Dev, 47:94-101.

[8] Oerbeck, B., Stein, M., B., Pripp, A., H., \& Kristensen, H. (2015). Selective Mutism: Follow-up Study 1 Year after end of treatment. Eur Child Adolesc Psychiatry, 24:757-766.

[9] Ruangdaraganon, N., Chuthapisith, J., Mo-Suwan, L., Kriweradechaichai, S., Udomsubpayakul, U., \& Choprapawon, C. (2009). Television Viewing in Thai Infants and Toddlers: Impacts to Language Development and Parental Perceptions. BMC Pediatrics. 9(24).1-6. doi:10.1186/14712431-9-34

[10] Steinberg, D., D., Nagata, H., \& Aline, D., P. (2001). Psycholinguistics: Language, Mind and World (2nd Ed). Edinburgh: Pearson Education. 